\title{
PLANNING OF PERSONAL TRAJECTORS OF DEVELOPMENT: SYSTEMS OF AUTOMATED DESIGN
}

\author{
S.A. Bogatenkov ${ }^{1}$, ser-bogatenkov@yandex.ru, \\ N.D. Yusubov², nizami_yusubov@mail.ru \\ ${ }^{1}$ South Ural State University, Chelyabinsk, Russian Federation, \\ ${ }^{2}$ Azerbaijan Technical University, Baku, Azerbaijan
}

\begin{abstract}
The problem of planning personal development trajectories in the implementation of computeraided design systems in conditions of uncertainty and risk is considered. The aim of the research is the network planning of personal development trajectories when implementing computer-aided design systems on the basis of a competency model that requires reasoning. To minimize risks, a level model of competencies has been developed, taking into account education, work experience, certificates and functional responsibilities. The process of building a competency model for the implementation of automated process design systems is described. The developed algorithm and the program allows to solve the problem of network planning of personal development trajectories by the criteria of minimization of time and cost costs. The results of the research are used in the educational process of the South Ural State University and the Azerbaijan Technical University when training personnel for work with the systems of computer-aided design of technological processes.

Keywords: computer-aided design systems, personal development trajectories, modeling, competences.
\end{abstract}

\section{Introduction}

The modern information society is distinguished by the extensive use of computer technology tools. The Russian Internet audience, the largest in Europe, exceeds 80 million users; 62 million of them are online every day. The commercial segment of the network is dynamically increasing. The volume of markets that are connected to the Internet is 16 percent of gross domestic product. The technology of remote access is actively used in the provision of state and municipal services, in 2014, more than a third of these municipal and state services were provided in an automated mode. The Internet is widely used to form a new technological basis of the domestic economy, in social sectors, in education, in healthcare [1].

The main objectives, which are incorporated in the program of the development of the digital economy in Russia until 2024, are: providing quick access to the Internet for every Russian, including residents of remote settlements; replacement of university diplomas and workbooks on development trajectories, "smart cities" and even an automated system for making government decisions [2].

The use of automated design systems ensures high efficiency of professional activity in the context of increasing requirements for the scope of design work and the timing of production $[3,4]$.

However, professional activities in the information society can be dangerous and lead to economic losses. The damage resulting from the use of new information technologies is commensurate with the annual growth of gross domestic product [5].

According to the experts of the American Institute of Project Management (PMI), the irreparable loss of organizations due to poor quality of project management amounts to $\$ 109$ million for every $\$ 1$ billion [6]. Approximately the same picture is observed with the fulfillment of complex and mega projects in Russia. Therefore, project management in practice implements not more than half of its capabilities.

This situation is explained by the increased risks of economic, informational, psychological, didactic and social nature.

First, a class of new economic threats emerged, associated with the emergence of a large number of CAD systems, differing in functional and cost characteristics. For example, at the end of the last century, a number of CAD systems were developed and implemented at the Chelyabinsk Polytechnic Institute at the Department of Engineering Technology, covering the design of both route and operational processes on various machine tools, including automation of transaction normalization [7]. Similar CAD systems 


\section{Краткие сообщения}

were developed in the institutes of other cities. There was a problem of economically justified choice of CAD.

Secondly, the process of introducing CAD (especially at the stage of trial operation) is accompanied by unreliable work, leading to distortion of information. New information threats appeared that require duplication of work of the technologist, both with the help of CAD, and in the traditional version, which leads to an increase in the labor intensity of the work.

Thirdly, the process of implementing CAD is accompanied by a change in the structure of the enterprise and the duties of the staff. A new class of psychological threats emerged, related to the need for the staff to be ready to work with CAD.

It is necessary to additionally take into account the threats that arise in the process of designing training in a practice-oriented education. On the one hand, the threat of didactic security increases due to the need to plan personal development trajectories for the training of personnel with different base competencies and work experience for specific job responsibilities. On the other hand, the threat of social security is growing, because a dilemma arises: either learn or "goodbye" [8].

Education is planned to be rebuilt for the needs of the digital economy. For graduates and students of the system of general, professional and additional education for all specialties, requirements will be developed for the formation of the basic competencies of the digital economy. Together with them, the competence in the field of the digital economy will be changed by federal state educational standards for all levels of education. A mechanism will be created for individual profiles of citizens' competencies and trajectories of their development. In such analogues of workbooks, the results of the educational and labor activity of citizens and the results achieved by them will be recorded. A personal trajectory of development will be established in educational institutions. With their help, the student can choose an individual way of forming the basic competences of the digital economy (formal, informal, informational). Personal trajectories will help in solving the problem of identifying talents at an early stage in the learning process. At the end of the educational institutions, personal trajectories will be transferred to the organizations in which the graduate will work. In case of dismissal of an employee, his personal trajectory will be transferred to the next employer. Potential employers, educational institutions and other organizations will have the opportunity, with the consent of the citizen and subject to the requirements of legislation on personal data, to gain access to his personal trajectory [9].

It is planned to choose an organization that will be responsible for developing and testing the competency model. Based on this organization, it is planned to create a group of experts from the business environment, the education system and government authorities. This group of experts will develop a model extensible structure of the competence model and a list of competences for the digital economy, define the core competencies [10].

\section{Terms of reference}

There are different approaches to solving the problems of managing the implementation of computer technology. The first approach is based on the use of experience, the second - on the use of mathematical models.

Examples of the first approach include the experience of implementing a distributed information system in a multi-branch organization using the example of FSUE Russian Post [11] and information and measuring systems at Chelyabinsk CHPP-2.

The second approach is based on comparing the actual state of the system with an estimate obtained using its mathematical model, which can be developed on the basis of theoretical laws or experimental data. To create mathematical models from experimental data, the methods of principal components and eigenstates are used [12], as well as multidimensional interpolation and approximation based on the theory of random functions [13]. For the development of a security system, model composition and evaluation of the effectiveness of recommended activities are used.

Personal development trajectories are developed on the basis of a competence approach, which is widely used in the development of methodological training systems.

However, the complexity of analyzing competences formulated in a natural language can lead to significant economic and didactic risks in solving a number of design problems in education.

First, when designing personal development paths, it is necessary to take into account competencies that include both basic education and practical work experience. In addition, it is necessary to take into 
account the requirements of employers, reflecting both professional standards and job descriptions. Studies in the field of vocational education showed that insufficient consideration of the basic competencies of students can lead to errors in the design of educational material, exceeding $20 \%$ of the training load [8].

Secondly, when developing thematic plans of disciplines for conducting simultaneous lecture classes for students of groups of different areas of preparation there may be risks of didactic nature, due to insufficient educational information for the formation of assigned competencies, and economic nature associated with the redundancy of educational information.

Traditionally, these tasks are solved approximately both on the basis of experience acquired by trial and error, and on the basis of the classification of competences in educational standards [8].

However, the traditional approach cannot be fully used to design the development trajectories, since it, on the one hand, is very approximate and laborious, on the other hand, does not take into account the practical experience of work and the availability of appropriate certificates.

A promising area for planning personal development paths is the application of network modeling methods. These methods are widely used in planning and managing the development of large national economic complexes, scientific research, design and technological preparation of production, development of new types of products, construction and reconstruction, major repairs of fixed assets. Network modeling is based on the application of a model of a set of interrelated works aimed at achieving a specific goal [14].

The aim of the research is the network planning of personal development trajectories when implementing computer-aided design systems on the basis of a competency model that requires reasoning.

The subject of the study is level models of competences that take into account education, work experience, certificates and functional responsibilities.

\section{Construction of competency model}

Under the model of competencies we will understand a model that includes the amount of knowledge, skills and skills that are sufficient to fulfill the functional duties of a specialist in accordance with his job description.

As a research object, a control system for the introduction of the automated design system by technological processes was chosen. Based on the analysis and generalization of the experience of introducing the system of automated design by technological processes, a level model of competences has been developed (Table 1).

Level model of competences for work with systems of computer-aided design

Table 1 of technological processes (CAD TP)

\begin{tabular}{|c|c|c|c|c|}
\hline Option & Education & $\begin{array}{c}\text { Experience, } \\
\text { months }\end{array}$ & Certificate & Functional duties \\
\hline 1.1 & Average & 6 & \multirow{2}{*}{$\begin{array}{l}\text { Job description of } \\
\text { the technician for working } \\
\text { with CAD TP } \\
\end{array}$} & \multirow{2}{*}{$\begin{array}{l}\text { Preparation of technological } \\
\text { documentation with the help } \\
\text { of CAD TP }\end{array}$} \\
\hline 1.2 & $\begin{array}{l}\text { Secondary } \\
\text { vocational }\end{array}$ & 0 & & \\
\hline 2.1 & \begin{tabular}{|l|} 
Secondary \\
or secondary \\
vocational
\end{tabular} & 12 & \multirow{2}{*}{$\begin{array}{l}\text { Job description of } \\
\text { the technologist on working } \\
\text { with CAD TP }\end{array}$} & \multirow{2}{*}{$\begin{array}{l}\text { Technological preparation } \\
\text { of production with the help } \\
\text { of CAD TP }\end{array}$} \\
\hline 2.2 & $\begin{array}{l}\text { Bachelor's } \\
\text { or Specialty }\end{array}$ & 6 & & \\
\hline 3.1 & $\begin{array}{l}\text { Bachelor's } \\
\text { or Specialty }\end{array}$ & 24 & \multirow{2}{*}{$\begin{array}{l}\text { Job description of the leading } \\
\text { technologist on working } \\
\text { with CAD TP }\end{array}$} & \multirow{2}{*}{$\begin{array}{l}\text { Optimization of technological } \\
\text { preparation of production using } \\
\text { CAD TP }\end{array}$} \\
\hline 3.2 & $\begin{array}{l}\text { Master's } \\
\text { Courses }\end{array}$ & 6 & & \\
\hline 4.1 & $\begin{array}{l}\text { Master's } \\
\text { Courses }\end{array}$ & 36 & $\begin{array}{l}\text { Job description of the head } \\
\text { of the department for work } \\
\text { with CAD TP }\end{array}$ & $\begin{array}{l}\text { Leadership of the department for } \\
\text { work with CAD TP; management } \\
\text { control and task planning of } \\
\text { the unit; staff motivation to achieve } \\
\text { results }\end{array}$ \\
\hline
\end{tabular}




\section{Краткие сообщения}

The application of the competency model allows you to manage development trajectories with the help of factors of education and work experience based on the methods of network modeling.

The model satisfies a number of requirements that ensure the solution of the problem of planning an effective personal development trajectory.

First, the model is sufficiently effective, since it takes into account all employers' requirements for education, work experience, certification and functional duties.

Secondly, the model allows you to manage the parameters of education and work experience while moving to the next level of competencies. For example, a technician can be a person who has a secondary education and has passed a six-month probationary period or a person with a secondary vocational education without having to submit requirements for work experience.

Thirdly, the model allows solving the problem in the optimization statement, because provides the formation of a variety of options:

1) $0=>1.1=>2.2=>3.1=>4.1$

2) $0=>1.1=>2.2=>3.2=>4.1$

3) $0=>1.1=>2.2=>3.2=>4.2$;

4) $0=>1.2 \Rightarrow 2.1=>3.1=>4.1$

5) $0=>1.2 \Rightarrow>2.2=>3.1=>4.1$

6) $0=>1.2=>2.2=>3.2=>4.1$;

7) $0=>1.2=>2.2=>3.2=>4.2$.

\section{Network planning of personal trajectors of development}

The basis of the logical relationship is the technological and resource (time and cost) dependence of states. The network graph, which is a graphic representation of the network model of personal development paths, is shown in Fig. 1.

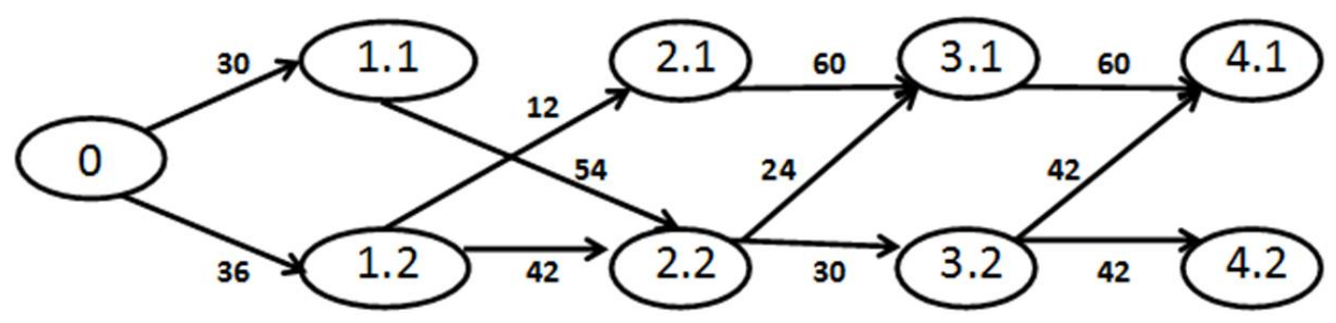

Fig. 1. Network diagram of development trajectories

Arcs of the schedule set the work on the formation of competencies for the transition to the next level, determined by the corresponding vertex (state). Each arc of the network graph (ij) is assigned a number indicating the duration of the work, which is defined as the sum of the time necessary to obtain the required level of education and work experience (see Fig. 1). Here $i$ and $j$ denote the numbers of the initial and final events of the arc.

The set of arcs, ordered in such a way that the final event of one of them is the initial event of the other, is called the development trajectory. The path of development is called complete if its beginning coincides with the initial (zero) event, and the end with the final one.

A large number of variants of complete personal development trajectories makes it possible for them to plan in an optimization formulation by the criterion of minimizing time or cost. To solve these problems, we use known methods for finding the shortest paths on a graph with given values of arcs. Table 2 shows the estimated duration of various versions of personal development trajectories.

Analysis of the calculated data shows that the most effective in duration are the variants of trajectories 7 and 8 (150 months).

The results of the research are used in the educational process of the South Ural State University and the Azerbaijan Technical University in training personnel for work with systems of automated design of technological processes. 
Calculation of interim costs in planning full trajectories of development

\begin{tabular}{|c|c|c|}
\hline Option & Sequence levels & Time, month \\
\hline 1 & $0=>1.1=>2.2=>3.1=>4.1$ & 168 \\
\hline 2 & $0=>1.1=>2.2=>3.2=>4.1$ & 156 \\
\hline 3 & $0=>1.1=>2.2=>3.2=>4.2$ & 156 \\
\hline 5 & $0=>1.2=>2.1=>3.1=>4.1$ & 164 \\
\hline 6 & $0=>1.2=>2.2=>3.1=>4.1$ & 162 \\
\hline 7 & $0=>1.2=>2.2=>3.2=>4.1$ & 150 \\
\hline 8 & $0=>1.2=>2.2=>3.2=>4.2$ & 150 \\
\hline
\end{tabular}

\section{Conclusion}

The task of network planning of personal development trajectories in the control system for the introduction of automated design systems by technological processes was solved.

To minimize risks, a level model of competencies has been developed, taking into account education, work experience, certificates and functional responsibilities.

The process of building a competency model for the implementation of automated process design systems is described.

The developed algorithm and the program allow solving the problem of network planning of personal development trajectories by the criteria of minimization of time and cost costs.

The results of the research are used in the educational process of the South Ural State University and the Azerbaijan Technical University in training personnel to work with systems of automated design of technological processes.

\section{References}

1. Russian Forum Internet Economy, 2015. Available at: http://ie.iri.center (accessed 29.12.2016).

2. Umnyye lyudi, umnyye goroda: chto nado znat' o programme razvitiya tsifrovoy ekonomiki [Smart People, Smart City: What You Need to Know about the Program of Development of the Digital Economy]. Available at: http://tass.ru/ekonomika/4306382 (accessed 01.08.2017).

3. Kondakov A.I. SAPR tehnologicheskih processov: uchebnik [CAD Processes: Tutorial]. Moscow, Academy Publ., 2010. 268 p.

4. Korchak S.N. (Ed.) Sistemi avtomatizirovannogo proektirovaniya tekhnologicheskikh protsessov, prisposobleniy i rezhuschikh instrumentov: uchebnik [Computer-Aided Technological Processes Design Fixtures and Cutting Tools: Tutorial]. Moscow, Mechanical Engineering Publ., 1988. 352 p.

5. Tolmachev V.D. [On the Staffing of Modern Energy]. Energy Security and Energy Conservation, 2011, no. 1, pp. 37-38. (in Russ.)

6. Poznyakov V.V. [Project Management for Top Managers]. Project and Program Management, 2012, no. 3, pp. 224-236. (in Russ.)

7. Sazonova N.S., Koshin A.A. Sistemy avtomatizirovannogo proektirovaniya tekhnologicheskikh protsessov. Ch. 2: SAPR pervogo pokoleniya: uchebnoe posobie [Computer Aided Design of Technological Processes. Part 2: CAD of the First Generation: Tutorial]. Chelyabinsk, South Ural St. Univ. Publ., 2014. 301 p.

8. Gnatyshina E.A., Bogatenkov S.A., Gnatyshina E.V., Uvarina N.V. Informatsionnaya podgotovka pedagogov professional'nogo obucheniya $v$ aspekte bezopasnosti [Information Training of Teachers of Professional Training in the Aspect of Safety]. Chelyabinsk, Chelyab. State. Ped. Univ. Publ., 2015. 415 p.

9. Program for Putin: How Russians Will Be Forced to Love the Digital Economy. News cnews. Available at: http://www.cnews.ru/news/top/2017-08-11_programma_dlya_putina_kak_rossiyan_ zastavyat_polyubit (accessed 20.11.2017).

10. Digital Economy: How the Labor Market Will Change from 2018 to 2025. Neohr. Available at: http://neohr.ru/kadrovye-voprosy/article_post/tsifrovaya-ekonomika-kak-budet-menyatsya-rynok-trudas-2018-po-2025-gody (accessed 20.11.2017). 


\title{
Краткие сообщения
}

11. Morgunov A.F. [The Introduction of a Distributed Information System in a Multi-Branch Organization: the Experience of FSUE Russian Post]. Business Informatics, 2014, no. 1, pp. 34-41. (in Russ.)

12. Mokeyev V.V., Vorobiev D.A. Analysis of Socio-Economic System Processes Performance with the Help of Eigenstate Models. Bulletin of the South Ural State University. Ser. Mathematical Modeling and Programming, 2015, vol. 8, no. 1, pp. 66-75. DOI: 10.14529/mmp150105

13. Kolchev K.K., Mezin S.V. [Construction of Mathematical Models of Processes of Heat and Power Equipment on the Basis of Statistical Methods of Approximation]. Thermal Engineering, 2015, no. 7, pp. 44-51. (in Russ.)

14. Gel'rud Ya.D., Loginovskiy O.V. Upravlenie proektami: metody, modeli, sistemy: monografiya [Project Management: Methods, Models, Systems: Monograph]. South Ural St. Univ. Publ., 2015. 330 p.

Received 5 May 2018

УдК 681.31

DOI: $10.14529 /$ ctcr190113

\section{ПЛАНИРОВАНИЕ ПЕРСОНАЛЬНЫХ ТРАЕКТОРИЙ РАЗВИТИЯ: СИСТЕМЫ АВТОМАТИЗИРОВАННОГО ПРОЕКТИРОВАНИЯ}

\author{
С.А. Богатенков ${ }^{1}$, Н.Д. Юсубов ${ }^{2}$ \\ ${ }^{1}$ Южно-Уральский государственный университет, г. Челябинск, Россия, \\ ${ }^{2}$ Азербайджанский технический университет, г. Баку, Азербайджан
}

\begin{abstract}
Рассматривается задача планирования персональных траекторий развития при внедрении систем автоматизированного проектирования в условиях неопределенности и риска. Целью исследования является сетевое планирование персональных траекторий развития при внедрении систем автоматизированного проектирования на основе модели компетенций, требующей рассуждений. Для минимизации рисков разработана уровневая модель компетенций, учитывающая образование, опыт работы, сертификаты и функциональные обязанности. Описан процесс построения модели компетенций при внедрении систем автоматизированного проектирования технологических процессов. Разработанный алгоритм и программа позволяют решать задачу сетевого планирования персональных траекторий развития по критериям минимизации временных и стоимостных затрат. Результаты исследования используются в учебном процессе Южно-Уральского государственного университета и Азербайджанского технического университета при подготовке кадров к работе с системами автоматизированного проектирования технологическими процессами.
\end{abstract}

Ключевые слова: системы автоматизированного проектирования, персональные траектории развития, моделирование, компетенциии.

\footnotetext{
Лuтература

1. Российский форум Интернет Экономика. - 2015. - http://ie.iri.center (дата обращения: 29.12.2016).

2. Умные люди, умные города: что надо знать о программе развития ијифровой экономики. 2017. - http://tass.ru/ekonomika/4306382 (дата обращения: 01.08.2017).

3. Кондаков, А.И. САПР технологических проиессов: учеб. для вузов / А.И. Кондаков. - М.: Академия, 2010. - 268 с.

4. Системы автоматизированного проектирования технологических процессов, приспособлений и режуших инструментов: учеб. для вузов / под. ред. С.Н. Корчака. - М.: Машиностроение, 1988. - 352 c.

5. Толмачев, В.Д. О кадровом обеспечении современной энергетики / В.Д. Толмачев // Энергобезопасность и энергосбережение. - 2011. - № 1. - С. 37-38.
} 
6. Позняков, В.В. Управление проектами для топ-менеджеров / В.В. Позняков // Управление проектами и программами. - 2012. - № 3. - С. 224-236.

7. Сазонова, Н.С. Системы автоматизированного проектирования технологических прочессов. Ч. 2: САПР первого поколения: учеб. пособие / Н.С. Сазонова, А.А. Кошин; под ред. А.А. Кошина. - Челябинск: Издат. иентр ЮУрГУ, 2014. - 301 с.

8. Информачионная подготовка педагогов профессионального обучения в аспекте безопасности: моногр. / Е.А. Гнатышина, С.А. Богатенков, Е.В. Гнатышина, Н.В. Уварина. - Челябинск: Изд-во Челяб. гос. пед. ун-та , 2015. - 415 с.

9. Программа для Путина: Как россиян заставят полюбить иифровую экономику // Новости cnews. - 2017. - http://www.cnews.ru/news/top/2017-08-11_programma_dlya_putina_kak_rossiyan_ zastavyat polyubit (дата обращения: 20.11.2017).

10. Цифровая экономика: как будет меняться рынок труда с 2018 до 2015 годы // Neohr. 2017. - http://neohr.ru/kadrovye-voprosy/article post/tsifrovaya-ekonomika-kak-budet-menyatsyarynok-truda-s-2018-po-2025-gody (дата обращения: 20.11.2017).

11. Моргунов, А.Ф. Внедрение распределенной информационной системы в многофилиальной организачии: опыт ФГУП «Почта России» / А.Ф. Моргунов // Бизнес-информатика. - 2014. № 1. - C. 34-41.

12. Mokeyev, V.V. Analysis of Socio-Economic System Processes Performance with the Help of Eigenstate Models / V.V. Mokeyev, D.A. Vorobiev // Вестник ЮУрГУ. Серия «Математическое моделирование и программирование». - 2015. - T. 8, № 1. - C. 66-75. DOI: 10.14529/mmp150105

13. Колчев, К.К. Построение математических моделей технологических прочессов теплоэнергетического оборудования на основе статистических методов аппроксимации / К.К. Колчев, С.В. Мезин // Теплоэнергетика. - 2015. - № 7. - С. 44-51.

14. Гельруд, Я.Д. Управление проектами: методы, модели, системы: моногр. / Я.Д. Гельруд, О.В. Логиновский; под ред. д-ра техн. наук, проф. А.Л. Шестакова. - Челябинск: Издат. иентр ЮУрГУ, 2015. - 330 c.

Богатенков Сергей Александрович, канд. техн. наук, доцент кафедры информационных технологий в экономике, Южно-Уральский государственный университет, г. Челябинск; ser-bogatenkov@yandex.ru.

Юсубов Низами Дамир оглы, д-р техн. наук, заведующий кафедрой технологии машиностроения, Азербайджанский технический университет, г. Баку, Азербайджан; nizami_yusubov@ mail.ru.

Поступила в редакцию 5 мая 2018 г.

\section{ОБРАЗЕЦ ЦИТИРОВАНИЯ}

Bogatenkov, S.A. Planning of Personal Trajectors of Development: Systems of Automated Design / S.A. Bogatenkov, N.D. Yusubov // Вестник ЮУрГУ. Серия «Компьютерные технологии, управление, радиоэлектроника». - 2019. - Т. 19, № 1. - С. 139-145. DOI: $10.14529 / \operatorname{ctcr} 190113$

\section{FOR CITATION}

Bogatenkov S.A., Yusubov N.D. Planning of Personal Trajectors of Development: Systems of Automated Design. Bulletin of the South Ural State University. Ser. Computer Technologies, Automatic Control, Radio Electronics, 2019, vol. 19, no. 1, pp. 139-145. DOI: $10.14529 /$ ctcr190113 